Proceedings

\title{
Short and Efficient First Total Synthesis of the Natural Product Chromanone A, a Chromone Derivative from the Algicolous Marine Fungus Penicillium sp. ${ }^{+}$
}

\author{
Iván Cortés *, Teodoro S. Kaufman and Andrea B. J. Bracca * \\ Instituto de Química Rosario IQUIR (CONICET-UNR), and Facultad de Ciencias Bioquímicas y \\ Farmacéuticas, Universidad Nacional de Rosario (UNR), Suipacha 531 (2000), Rosario, Argentina \\ * Correspondence: bracca@iquir-conicet.gov.ar (A.B.J.B.) \\ + Presented at the 24th International Electronic Conference on Synthetic Organic Chemistry, \\ 15 November-15 December 2020; Available online: https://ecsoc-24.sciforum.net/.
}

Received: date; Accepted: date; Published: date

\begin{abstract}
In 2009, Gamal Eldeen et al. described the isolation and structural elucidation of chromanone A. This natural product is produced by a Penicillium sp., an endophyte isolated from the Egyptian green algae Ulva sp., grown in a solid medium with biomalt. The authors evaluated its chemopreventive activity against cancer (CYP1A inhibitor). Furthermore, the natural product was shown to possess potent hydroxyl and peroxyl radical scavenging activity. In this work, we detail the first total synthesis of chromanone A in multiple stages from the inexpensive commercial product pyrocatechol and without the use of protecting groups.
\end{abstract}

Keywords: total synthesis; natural product; chromanone A; Kornblum oxidation

\section{Introduction}

Recently, interest in marine microorganisms, particularly fungi, has increased significantly since they have shown an ample variety of diverse and novel chemical structures with powerful biological activities [1].

Marine-derived fungi have yielded some unique biologically active metabolites, such as ascosalipyrrolidinone and ascosalipyrone [2], microsphaeropsisin [3], and anomalin A [4]; this supports the idea that these organisms are important producers of potential therapeutic agents of great interest.

Fungi of the genus Penicillium (Ascomycota) are well known as plant pathogens but they are also notable for their production of secondary metabolites with significant biological activities. To date, many fungal compounds belonging to this genus have been reported, for example, xestdecalactones A-C [5]; unique steroids, isocyclocitrinol A and 22-acetylisocyclocitrinol A [6] (Figure 1). Among the interesting compounds produced by marine fungi is chromanone A. In particular, this natural product was isolated from the algicolous marine fungus Penicillium sp., which was cultivated in a solid biomalt medium and its EtOAc extract was fractionated by liquid vacuum chromatography (VLC) [7]. 


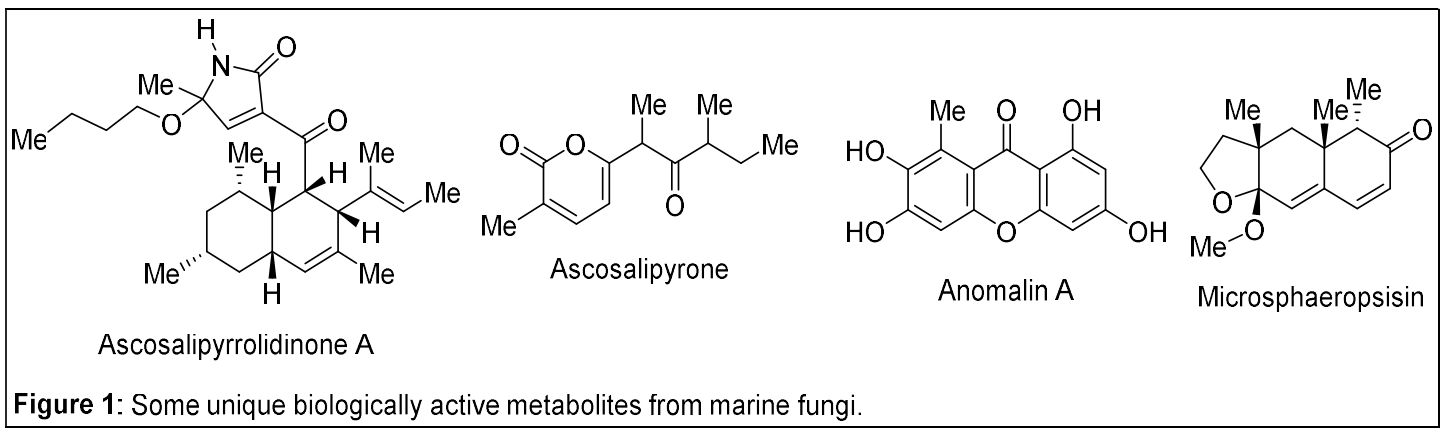

Chromones (4H-chromen-4-one) are heterocycles fused to an aromatic ring, where the oxygen atom is attached to the aromatic moiety, and are characterized by having a carbonyl group in ring position 4 , forming an $\alpha, \beta$-unsaturated system. These building blocks are a group of naturally occurring compounds that are present in nature, especially in plants.

Chromones are among those known as "privileged structures" as they are promising compounds for medicinal chemistry and drug development; numerous biological activities have been attributed to simple chromones and analogues, such as anti-inflammatory, antiplatelet, anticancer, and antimicrobial activities, including those related with central nervous system and obesity [8].

\section{Results and Discussion}

The retrosynthetic sequence (Scheme 1) begins by proposing that chromanone A (1) would come from the reduction of allyl aldehyde 2 , which could be obtained from $O$-methylation with subsequent allylic oxidation of chromone 3. In turn, this intermediate could be obtained through the Kostanecki-Robinson reaction of ketone 4, which would be the product of a Friedel-Crafts acylation reaction of commercial pyrocatechol (5).<smiles>COc1cccc2c(=O)c(C)c(CCCO)oc12</smiles>

1

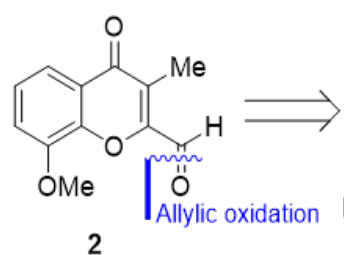

2
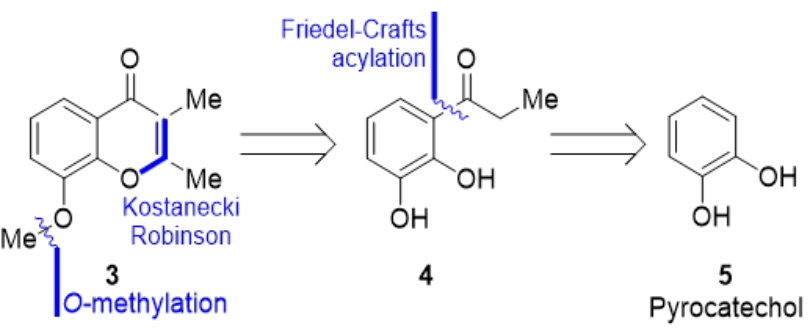

Scheme 1: Retrosynthetic analysis of chromanone A (1).

Therefore, the synthesis commenced with pyrocatechol (5), which was submitted to a Friedel-Crafts acylation in a closed tube, with propionic acid and $\mathrm{BF}_{3} . \mathrm{OEt}_{2}$ as Lewis acid in an inert argon atmosphere at $80{ }^{\circ} \mathrm{C}$ under microwave irradiation (Scheme 2) [9]. This reaction provided 4 with an average yield of $61 \%$. It was observed that the reaction conditions lack robustness and small changes in the experimental conditions caused large differences in performance, even to the point of affording total decomposition of the starting material. 


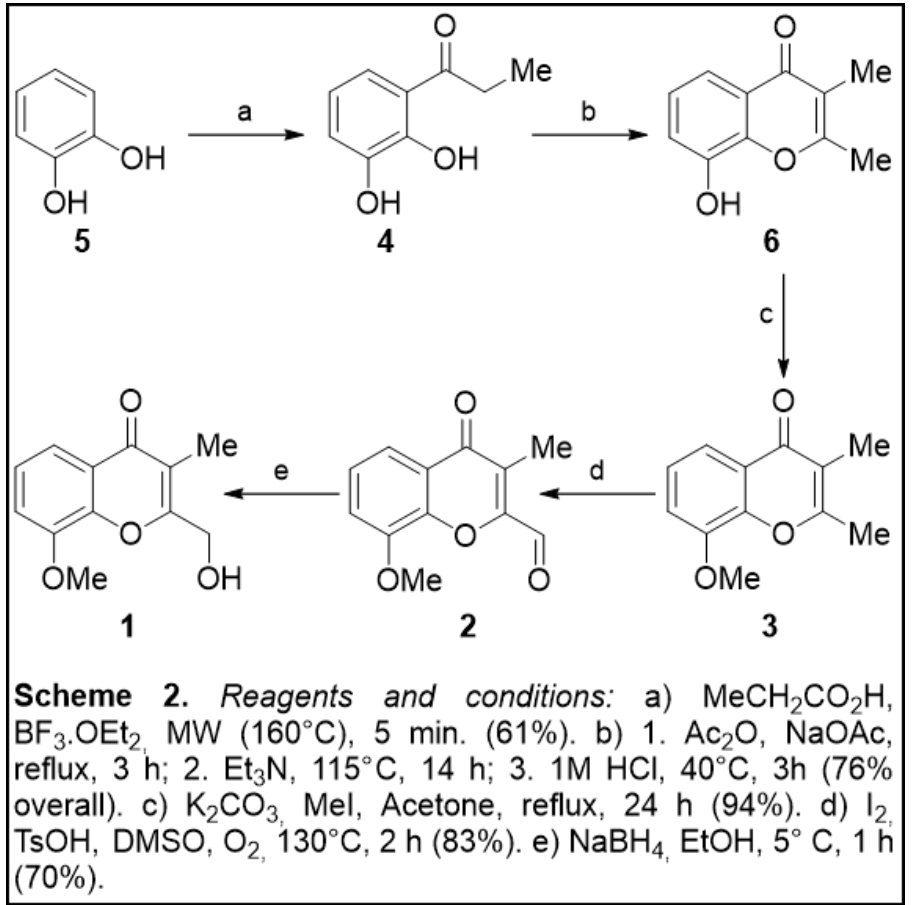

Then, we carried out the Kostanecki-Robinson cyclization [10]; this procedure included three steps that were performed as a one-pot reaction. The first stage consisted of an acetylation of the free phenols, for which it was necessary to use acetic anhydride as acetylating agent and sodium acetate as a soft base. The reaction mixture was heated in a closed tube under reflux for three hours. Once completion of the reaction was verified by thin layer chromatography (TLC), the excess of $\mathrm{Ac}_{2} \mathrm{O}$ was removed by distillation under reduced pressure, the residue was suspended in EtOAc and the remaining $\mathrm{NaOAc}$ was filtered off under reduced pressure.

For the second stage, it was necessary to use a stronger base to achieve the cyclization reaction, that is why the acetates obtained were treated with anhydrous triethylamine and the mixture was heated for $14 \mathrm{~h}$ at $115{ }^{\circ} \mathrm{C}$. After this period, the reaction was cooled to room temperature and the solvent was removed under reduced pressure. Finally, the residue was treated with $1 \mathrm{M} \mathrm{HCl}$ solution at $5{ }^{\circ} \mathrm{C}$ and then, the resulting suspension was stirred for $6 \mathrm{~h}$ at $40^{\circ} \mathrm{C}$. The white precipitate formed was filtered under reduced pressure and washed with water at $5{ }^{\circ} \mathrm{C}$, providing 6 with $76 \%$ overall yield.

Subsequently, a typical O-methylation of the free phenolic residue was performed. For this Williamson-type reaction, a solution of $\mathbf{6}$ in acetone was treated with MeI as a methylating agent in the presence of $\mathrm{K}_{2} \mathrm{CO}_{3}[11]$.

With 3 in our hands, we were able to carry out an elegant and innovative allylic oxidation. In this case, the reaction was performed under aerobic conditions (in a closed reaction tube with $\mathrm{O}_{2}$ ), using $\mathrm{TsOH}$ and $\mathrm{I}_{2}$ in anhydrous DMSO as solvent.

Based on previous literature [12], a possible mechanism for this transformation, via Kornblum oxidation, is proposed in Scheme 3. At first, the carbonyl group of substrate $\mathbf{3}$ is activated by the added $\mathrm{TsOH}$, giving rise to $I$, which is then subjected to deprotonation to provide intermediate II. This is followed by iodination with $\mathrm{I}_{2}$, under DMSO activation to generate the benzylic intermediate III. Then, the iodide III would suffer a $\mathrm{SN}_{2}$ reaction with the nucleophilic oxygen atom of the DMSO to form the alkoxysulfonium salt $I V$ which, through deprotonation and subsequent [2,3]-sigmatropic shift would afford the carbonyl compound 6 . It is assumed that the oxygen would serve to reoxidize the resulting dimethyl sulfide $\left(\mathrm{SMe}_{2}\right)$. 


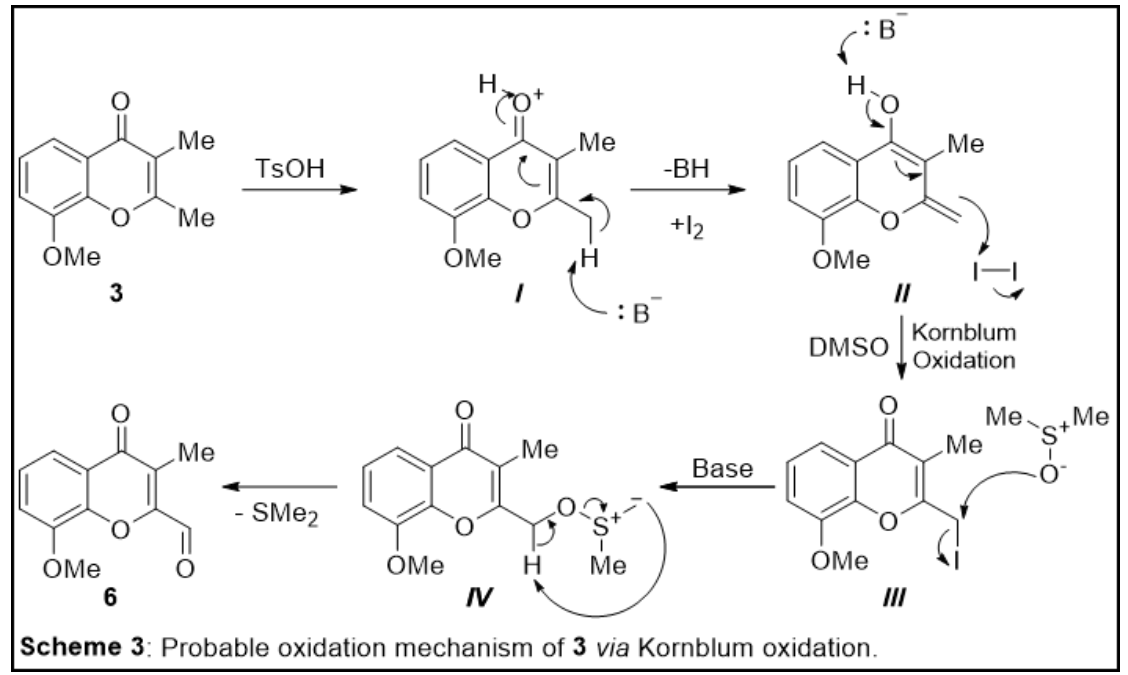

Finally, aldehyde 2 was reduced in the presence of $\mathrm{NaBH}_{4}$, using ethanol as solvent at $5{ }^{\circ} \mathrm{C}$ for one hour [13]. This reaction provided the natural product chromanone A in $70 \%$ yield.

\section{Experimental Section}

\subsection{General Experimental Details}

The reactions were executed with oven-dried glassware and freshly distilled anhydrous solvents. The reactions were monitored by TLC, where the spots were detected by exposure to 254 nm UV light, and by spraying with ethanolic $p$-anisaldehyde $/ \mathrm{H}_{2} \mathrm{SO}_{4}$. All new compounds gave single spots on TLC plates run in different solvent systems. The flash column chromatographies were run with silica gel $60 \mathrm{H}$ (particle size 63-200 $\mu \mathrm{m}$ ), eluting under positive pressure with hexane-EtOAc mixtures, and employing gradient of solvent polarity techniques.

The melting points were measured on an Ernst Leitz Wetzlar model 350 hot-stage microscope and are informed uncorrected. The FT-IR spectra were acquired with a Shimadzu Prestige 21 spectrophotometer, with the samples as thin films held between $\mathrm{NaCl}$ cells or prepared as solid dispersions in $\mathrm{KBr}$ disks. The $\mathrm{NMR}$ spectra were recorded in $\mathrm{CDCl}_{3}$ on a Bruker Avance 300 spectrometer, at $300.13\left({ }^{1} \mathrm{H}\right)$ and $75.48\left({ }^{13} \mathrm{C}\right) \mathrm{MHz}$. High-resolution mass spectra were obtained from UMYMFOR (Buenos Aires, Argentina) with a Bruker MicroTOF-Q II instrument. Detection of the ions was performed in electrospray ionization, positive ion mode.

\subsection{Compound Characterization}

2-(hydroxymethyl)-8-methoxy-3-methyl-4H-chromen-4-one (1).- Yellow solid; yield: 70\%. ${ }^{1} \mathrm{H}$ NMR $\left(\mathrm{CDCl}_{3}, 300 \mathrm{MHz}\right): \delta=7.74(1 \mathrm{H}, \mathrm{dd}, J=1.4,8.1 \mathrm{~Hz}, \mathrm{H}-5), 7.28(1 \mathrm{H}, \mathrm{t}, J=8.1 \mathrm{~Hz}, \mathrm{H}-6), 7.12(1 \mathrm{H}, \mathrm{dd}, J=$ 1.4, $8.1 \mathrm{~Hz}, \mathrm{H}-7), 4.74(2 \mathrm{H}, \mathrm{s}, \mathrm{H}-1), 3.96(3 \mathrm{H}, \mathrm{s}, \mathrm{OMe})$ and $2.11(3 \mathrm{H}, \mathrm{s}, \mathrm{Me}) .{ }^{13} \mathrm{C} \mathrm{NMR}\left(\mathrm{CDCl}_{3}, 75 \mathrm{MHz}\right)$ : $\delta=178.3$ (C-4), 160.5 (C-2), 148.5 (C-8), 146.2 (C-8a), 124.5(C-6), 123.6 (C-4a), 117.4 (C-5), 116.8 (C-6), $113.8(\mathrm{C}-7), 60.4\left(\mathrm{CH}_{2}\right), 56.2(\mathrm{OMe}), 9.2(\mathrm{Me})$.

8-methoxy-3-methyl-4-oxo-4H-chromene-2-carbaldehyde (2).- Yellowish brown solid; yield: 83\%. ${ }^{1} \mathrm{H}$ NMR $\left(\mathrm{CDCl}_{3}, 300 \mathrm{MHz}\right): \delta=10.13(1 \mathrm{H}, \mathrm{s}, \mathrm{CHO}), 7.67(1 \mathrm{H}, \mathrm{dd}, J=1.4,8.1 \mathrm{~Hz}, \mathrm{H}-5), 7.26(1 \mathrm{H}, \mathrm{t}$, $J=8.1 \mathrm{~Hz}, \mathrm{H}-6), 7.13(1 \mathrm{H}, \mathrm{dd}, J=1.4,8.1 \mathrm{~Hz}, \mathrm{H}-7), 3.94(3 \mathrm{H}, \mathrm{s}, \mathrm{OMe}), 2.36(3 \mathrm{H}, \mathrm{s}, \mathrm{Me}) .{ }^{13} \mathrm{C} \mathrm{NMR}$ $\left(\mathrm{CDCl}_{3}, 75 \mathrm{MHz}\right): \delta=186.5\left(\mathrm{C}-1^{\prime}\right), 179.2$ (C-4), 150.5 (C-2), 149.1 (C-8), 145.9 (C-8a), 125.3 (C-6), 125.2 (C-3), 123.6 (C-4a), 116.6 (C-5), 114.9 (C-7), 56.4 (OMe), $8.2(\mathrm{Me})$. 


\section{Conclusions}

In this work we reported the development of the first total synthesis of the natural product chromanone A in only 5 stages and $25 \%$ overall yield. In addition, no protecting group was required and an innovative and efficient aerobic allylic oxidation strategy was used under mild oxidizing conditions to obtain an aldehyde as product.

The NMR signals of the synthetic chromanone A coincided with those previously reported in the work of Gamal Eldeen et al. [7].

Acknowledgments: The authors gratefully acknowledge Consejo Nacional de Investigaciones Científicas y Técnicas (CONICET, PUE IQUIR-2016), Agencia Nacional de Promoción Científica y Tecnológica (ANPCyT, PICT 2017-0149) and Agencia Santafesina de Ciencia, Tecnología e Innovación (ASACTeI, institutional grant AC 2015-0005) for financial support. I. C. also thanks CONICET for his doctoral fellowship.

\section{References}

1. König, G.; Wright, A. Planta Med. 1996, 62, 193-211.

2. Osterhage, C.; Kaminsky, R.; König, G.M.; Wright, A.D.J. Org. Chem. 2000, 65, 6412-6417.

3. Höller, U.; Wright, A.D.; Matthee, G.F.; Konig, G.M.; Draeger, S.; Aust, H.-J.; Schulz, B. Mycol. Res. 2000, 104, 1354-1365.

4. Abdel-Lateff, A.; Klemke, C.; König, G.M.; Wright, A.D.J. Nat. Prod. 2003, 66, 706-708.

5. Edrada, R.A.; Heubes, M.; Brauers, G.; Wray, V.; Berg, A.; Gräfe, U.; Wohlfarth, M.; Mühlbacher, J.; Schaumann, K.; Sudarsono; Bringmann, G.; et al. Nat. Prod. 2002, 65, 1598-1604.

6. Amagata, T.; Amagata, A.; Tenney, K.; Valeriote, F.A.; Lobkovsky, E.; Clardy, J.; Crews, P. Org. Lett. 2003, 5, 4393-4396.

7. Gamal-Eldeen, A.M.; Abdel-Lateff, A.; Okino, T. Environ. Toxicol. Pharmacol. 2009, 28, 317-322.

8. Gaspar, A.; Matos, M.J.; Garrido, J.; Uriarte, E.; Borges, F. Chem. Rev. 2014, 114, 4960-4992.

9. Naeimi, H.; Moradi, L. Bull. Chem. Soc. Jpn. 2005, 78, 284-287.

10. Helibron, I.M.; Barnes, H.; Morton, R.A.J. Chem. Soc. Trans. 1923, 123, 2559-2570.

11. Cortés, I.; Borini Etichetti, C.; Girardini, J.; Kaufman, T.; Bracca, A. Synthesis (Stuttg). 2019, 51, $433-440$.

12. Ye, R.; Cao, Y.; Xi, X.; Liu, L.; Chen, T. Org. Biomol. Chem. 2019, 17, 4220-4224.

13. Pergomet, J.L.; Larghi, E.L.; Kaufman, T.S.; Bracca, A.B.J. RSC Adv. 2017, 7, 5242-5250.

Publisher's Note: MDPI stays neutral with regard to jurisdictional claims in published maps and institutional affiliations.

(C) 2020 by the authors. Licensee MDPI, Basel, Switzerland. This article is an open access article distributed under the terms and conditions of the Creative Commons Attribution (CC BY) license (http://creativecommons.org/licenses/by/4.0/). 